\title{
TRACE ELEMENTS ACCUMULATION IN WALNUT GROWING ON RESIDENTIAL AREAS IN UKRAINE
}

\author{
Lidija Svirenko \\ Nataliya Butenko \\ Olga Khandogina \\ Kharkiv National Academy of Municipal Economy, Ukraine
}

\begin{abstract}
TheWalnut (Jugland regia L.) is wide spread on the territory of Ukraine. This big fine tree is grown both in orchards, park, in roadside green belts. It is popular for high nutritive value of their nuts, bactericidal properties of leaves, volatile production. Pilot investigation has been held to reveal trace elements accumulation in walnut depending on traits of environment in urban and rural areas.

Leaves and nuts of walnut have been sampled in 2003-2004 September in different parts of the country. Leaf, kernel and nutshell have been ashed and analysed (ESA) separately.

Main results of investigation are as follows: accumulation of phosphorus, copper, zinc and lead in kernel estimated; probably nutshell serves as a barrier for strontium accumulation in kernel; lead concentration is higher in kernel of walnut growing along motorway and may can reach sanitary limit; zinc concentration inversely is higher on rural areas; arsenic has been find in matter sampled near railway roads.

In future more detailed investigation of Walnut could make it possible to estimate the walnut as an instrument for pollution monitoring and control.
\end{abstract}

\section{KEYWORDS}

Walnut, trace element concentration, urban environment, motorway, railroad, environmental monitiring, leaf, nutshell, kernel.

\section{INTRODUCTION}

The Walnut (Juglans regia L.) is a big tree reached $25 \mathrm{~m}$ in high with power crone and thick stem (trunk). Leaves are alternating odd-pinnate with ovate green laminae. A fruit of the walnut is a drupe with green fleshy outer covering, hard light brown inner part (nutshell), and edible kernel inside with 2-5 partitions.

The walnut's system of roots is high developed and power if soil conditions are good enough and primary root can reach $4 \mathrm{~m}$ in depth and secondary roots $20 \mathrm{~m}$ in wide with thorns near the earth surace. Traits of the root system provides for walnut's ability to prevent soil erosion [1-5].

Walnut trees are destroyed by the frost at the temperature of $-\left(25-28^{\circ}\right)$.

The walnut is wide spread on the territory of Ukraine. It is popular for high nutritive value of their nuts, bactericidal properties of leaves and their ability for volatile production. This big 
fine tree is grown both in orchards, park, in roadside green belts because for its ability to improve light and temperature regime in urban environment.

Maine compounds of the kernel of nut are as follows: nut-oil (average content $65 \%$, highest $80 \%$ ), albumens - up to $18 \%$, carbonhydrates - up to $16 \%$. Reach set of amino acids belongs to specific trait of nut's core. Prevailing chemical elements in mineral matter of the kernel are $\mathrm{K}, \mathrm{Ca}, \mathrm{Mg}, \mathrm{Na}, \mathrm{S}, \mathrm{P}, \mathrm{Cl}$; as trace elements pointed out $\mathrm{Mg}, \mathrm{Cu}, \mathrm{Zn}, \mathrm{F}, \mathrm{J}[1,3]$.

The work is the result of pilot investigation has been held to reveal trace elements accumulation in walnut depending on traits of environment in urban and rural areas in Ukraine.

\section{METHODS OF INVESTIGATION}

Sampling of walnut trees have been held in Autum of years 2003-2004. Taking of sampls has been provided on the urban and rural areas in oblast's of Kharkiv, Lugans'k, Donets'k, Sumy, Hmelnitsky, Ivano-Frankivs'k, Kherson, the Crimea Autonomic Republic. The distance between the sampling point and the railway or motor road has been taken into consideration.

Matter from 12 points of sampling has been used for investigation. In the process of samples preparation for analyzing nuts, it was divided on nutshell and kernel to be analyzed separately. The weight of a standard sample was $20 \mathrm{~g}$.

Matters of samples (kernel, nutshell, leaves) have been dried and ashed at the temperature not higher then $500{ }^{\circ} \mathrm{C}$ (to condition of "the white ash") and for results of weighting the content of ash in organic matter has been calculated.

Content of trace element in different parts of plants has been determinated using EAS method of plants investigation [6].

Obtained results have been analysed with applying methods of mathematical statistics.

\section{RESULTS AND DISCUSSION}

The results of mathematical treatment of the obtained data are exposed in the table 1.

Table 1. Trace element concentration in walnut, $\mathrm{mg} / \mathrm{kg}$

\begin{tabular}{|c|c|c|c|c|c|c|c|c|}
\hline \multirow{2}{*}{ Index } & \multicolumn{9}{|c|}{ Environment } \\
\cline { 2 - 10 } & \multicolumn{3}{|c|}{ Urban area (n=8) } & \multicolumn{3}{c|}{ Rural area (n=4) } \\
\cline { 2 - 10 } & \multicolumn{2}{|c|}{ Nutshell } & \multicolumn{2}{|c|}{$\begin{array}{c}\text { Nut's core } \\
\text { (kernel) }\end{array}$} & \multicolumn{2}{c|}{ Nutshell } & \multicolumn{2}{c|}{$\begin{array}{c}\text { Nut' core } \\
\text { (kernel) }\end{array}$} \\
\cline { 2 - 10 } & average & $\sigma$ & average & $\sigma$ & average & $\sigma$ & average & $\sigma$ \\
\hline Copper & 122.5 & 40.3 & 120.0 & 78.0 & 100.0 & 40.8 & 110.0 & 60.0 \\
\hline Lead & 120.3 & 77.6 & 111.3 & 94.4 & 41.8 & 43.6 & 6.8 & 1.5 \\
\hline Zinc & 86.3 & 49.6 & 375.0 & 271.2 & 82.5 & 23.6 & 550.0 & 412.3 \\
\hline Nickel & 55.0 & 30.7 & 161.3 & 93.4 & 37.0 & 34.6 & 175.0 & 86.6 \\
\hline Ferrous & 14750 & 7498 & 13625 & 7558 & 11750 & 7676 & 3500 & 1915 \\
\hline Manganese & 577 & 245 & 1813 & 963 & 650 & 252 & 1500 & 408 \\
\hline Strontium & 418.7 & 293.0 & 166.3 & 105.0 & 187.5 & 85.4 & 120.0 & 54.2 \\
\hline Ash cont., \% & 4.5 & 3.7 & 2.8 & 1.6 & 3.3 & 2.8 & 3.1 & 2.8 \\
\hline
\end{tabular}


One can see there is no essential difference in total mineral (ash) content in kernel and nutshell as in urban areas as well in rural. At the same time concentration such chemical elements as $\mathrm{Zn}, \mathrm{Ni}, \mathrm{Fe}, \mathrm{Mn}$ is higher in kernel compare to nutshell and contrary accumulation of $\mathrm{Pb}$ and $\mathrm{Sr}$ occurs in nutshell.

Data concerning the walnut trees growing near motorways have been separated and compared with elements background concentration in soil (for Kharkiv region). Results are shown in the table 2.

Coefficient of trace element concentration in kernel of nut is $3.6-4,4$ for zinc, copper, and lead. The highest level of concentration is reached for phosphorous $(\mathrm{K}=7.1)$. Instead in leaves of walnut low meaning of coefficient of concentration for zinc and phosphorous can be observed and high $(\mathrm{K}=10)$ for lead. It could be an evidence of different sources of element entering in plant - from soil and from air. Strontium is concentrated in leaves too $(K=4)$, but in kernel its content may be estimated as normal probably for the nutshell activity as a screen. Besides arsenic concentration $(5-10 \mathrm{mg} / \mathrm{kg})$, it has also been determined in some walnut samples taken near railroads.

Table 2. Level of chemical element concentration in walnut (ash) growing along motorways in Kharkiv region

\begin{tabular}{|c|c|c|c|c|}
\hline Elements & $\begin{array}{c}\text { Background } \\
\text { concentration in } \\
\text { soil, mg/kg }\end{array}$ & $\begin{array}{c}\text { Kernel } \\
(\mathrm{n}=4)\end{array}$ & $\begin{array}{c}\text { Nutshell } \\
(\mathrm{n}=4)\end{array}$ & $\begin{array}{c}\text { Leaves } \\
(\mathrm{n}=2)\end{array}$ \\
\hline Phosphorous & 700 & 7.1 & 1.6 & 1.4 \\
\hline Ferrous & 14000 & 0.9 & 1.1 & 0.8 \\
\hline Manganese & 660 & 1.2 & 0.8 & 3.0 \\
\hline Copper & 27 & 3.7 & 3.9 & 2.4 \\
\hline Zinc & 70 & 3.6 & 1.1 & 1.1 \\
\hline Lead & 20 & 4.4 & 5.1 & 10.0 \\
\hline Strontium & 100 & 1.2 & 3.3 & 4.0 \\
\hline
\end{tabular}

Lead concentration in edible part of the nut calculated on the base of the element content in ash can reach meaning of $3-6 \mathrm{mg} / \mathrm{kg}$. It is limit for $\mathrm{Pb}$ content in food according sanitary rules valid in Ukraine [10].

\section{CONCLUSIONS}

Results of pilot investigation concerning trace elements concentration in Walnut trees in urbanised territories can be summarized as follows.

1 - Accumulation of copper, zinc and lead in kernel of the walnut has been estimated.

2 - Lead concentration is higher in kernel of walnut growing in urban areas along motorway and may reach sanitary limit.

3 - Zinc concentration in kernel of the nut inversely is higher on rural areas;

4 - Arsenic has been finding in matter of the walnut sampled near railway roads.

5 - High concentrations of lead and strontium in leaves of the walnut have been determined. For strontium this process has been known earlier [8,9].

6 - Nutshell probably could serve as a barrier for too high strontium concentration in kernel

7 - More detailed investigation could make it possible to estimate the Walnut as an instrument for pollution monitoring and control. 


\section{ACKNOWLEDGEMENTS}

We appreciate for assistance all former students of the Department of the Environmental Engineering \& Management that participated in the walnut sampling and investigation starting.

\section{REFERENCES}

[1] Pomogaybin A. V., Cavelenova L.M, Silaeva O.N., 2002. Nekotorye osobennosti khimicheskogo sostava i biologicheskoy aktivnosti listovogo opada vidov roda Orekh (Juglans L.) pri introdukcij v Srednem Povolzh'ye/ Khimiya rastitel'nogo sir'ja, (Some peculiarities of chemical content and biological activity of Walnut's (Juglands L.) Leaf litter growing in The Middle Povolzh'e / Plant Row materials. P. 43-47 (in Russian).

[2] Strela, T.E., 1990. Orech gretskiy: Spruvochnoje posobije (Walnut: Reference book). Kyiv (in Russian).

[3] Samusenko V.F., Golovina R.D., 1989. Pochvennye uslovija proizrastanija i zol'niy sostav oreha gretskogo $\mathrm{v}$ srednegor'yakh Ferganskogo khrebta/ Pochvovedeniye, ( Soil conditions and composition of walnut's ash in the Middle-high area of the Fergansky range// Soil sciens). P. 135-141(in Russian).

[4] Safarov I.S., 1981. Platan vostochniy, orekh gretskiy i ikh znacheniye v ozeleneniyi i lesonasagdeniyakh (Platan oriental and Walnut as species for planting and afforestration). Baku, AzerNeshr (in Russian).

[5] Izenman, B. E., Smirnov, V.V., and Bondarenko, A. C. 1984. Phitoncydy i antibiotiki vysshych rasteniy (Phytoncidics and antibiotics of Higher plants). Kiev, Ukraine (in Russian).

[6] Lapchinskaya L.V, Smislova L.I., Lapchinskaya Z.Y., Pahmurnaya G.S., 1988. Emissionnaya spectroskopiya kak metod izucheniya komponentov biosfery ( ESA as a method for biosphere's components investigation) / Vestnic Khar'kovskogo universiteta. Ratsional'noye prirodopol'zovaniye. Kharkiv, Ukraine (in Russian). 60-65.

[7] Fateev A.I, Paschenko Y. V., 2003. Fonoviy vmist microelementiv u gruntakh Ukrainy. (Background of trace element concentration in soils of Ukraine). Kharkiv (in Ukrainian).

[8] Warner, F., Harrison, R. M., 1999. Radioecology after Chernobyl. Biogeochemical Pathways of Artificial Radionuclides. UK, John Wiley \& Sons.

[9] Kondrushina, JU. N., Svirenko L. P. 2006. Nakoplenije Sr v rastenijach na territorii khar'kova (Ukraina).( Strontium accumulation in plants on the territory of the city of Kharkov.) /Proceedings of the $6^{\text {th }}$ Intern. Conference within the Frame of Forum "Ecobaltica", Saint-Petersburg. P.97-99. (In Russian)

[10] SanPin 42-123-4089-86, 1986. Predel'no dopustimiye kontsentratsiyi tyazholikh metalov i mish'yaka v prodovolstvennom sir'ye i pischevikh productakh (Limits of heavy metals and arsenic content in food). (In Ukrainian). 